\title{
Learning the Examples Non-Examples Model with the Help of PowerPoint to Improve Learning Outcomes in IPA
}

\section{Komariah}

SDN Karanggintung 05

komariah19860@gmail.com

\section{Article History}

accepted 14/11/2020

approved 21/11/2020

published 26/11/2020

\begin{abstract}
The objective of the research is to increase the result of learning Science through learning model of 'examples non examples' with power point. learning model of 'examples non examples' is a learning model which uses pictures related to basic competence. The result of the research obtains the increase score and the percentage of learning exhaustiveness. On the third cycle, the student learning exhaustiveness obtains $80,4 \%$. It refers to the success indicator established. The conclusion is that through learning model of 'examples non examples' can increase the result of Science learning.
\end{abstract}

Keywords: Examples non examples, powerpoint, learning result

\section{Abstrak}

Tujuan penelitian untuk meningkatkan hasil belajar IPA melalui pembelajaran model examples non examples dengan berbantuan powerpoint. Model pembelajaran examples non examples adalah suatu model pembelajaran yang menggunakan gambar yang sesuai dengan kompetensi dasar. Hasil penelitian diperoleh bahwa terdapat kenaikan rata-rata nilai dan prosentase ketuntasan belajar. Pada siklus 2 siswa yang tuntas $80 \%$, sesuai dengan ketercapaian indikator keberhasilan yang ditetapkan. Berdasarkan hasil yang telah dicapai maka dapat disimpulkan pembelajaran dengan menggunakan model examples non examples dapat meningkatkan hasil belajar IPA.

Kata kunci: Examples non examples, powerpoint, hasil belajar

Social, Humanities, and Education Studies (SHEs): Conference Series https://jurnal.uns.ac.id/shes

p-ISSN 2620-9284

e-ISSN 2620-9292 


\section{SHEs: Conference Series $x(x)(20 x x) 00-00$}

\section{PENDAHULUAN}

Siswa dalam belajar IPA lebih menekankan pada menghafal konsep, sehingga kurang memahami penerapan konsep-konsep dalam kehidupan sehari-hari. Kurangnya sarana dan prasarana penunjang pembelajaran misalnya mikroskop yang digunakan dalam proses pembelajaran sehingga membutuhkan waktu yang lama untuk mendapatkan gambar / konsep yang diharapkan. Disamping itu guru dalam mengajar kurang menggunakan media pembelajaran yang menarik dan bervariasi, sehingga tujuan belajar yang diharapkan tidak optimal, dapat dilihat pada hasil belajar yang rendah, sehingga pembelajaran kurang efektif .

Hasil analisisi nilai Ulangan mata pelajaran IPA kelas $V$ tahun pelajaran 2020/2021 di SD Negeri Karanggintung 05 dengan nilai rata-rata 60 dan ketuntasan belajar kurang dari $40 \%$. Nilai ulangan akhir kelas $\mathrm{V}$ yang di atas KKM hanya $12 \%$ dari 12 siswa atau hanya 1 siswa dengan nilai rata-rata 75 dan masih ada siswa dengan nilai 40 hal ini cukup memprihatinkan sehingga perlu dicari solusinya. Kriteria ketuntasan minimal untuk mata pelajaran IPA di kelas V SD Negeri Karanggintung 05 adalah 70 .

Hasil observasi ketika pelaksanaan pembelajaran, siswa kurang mampu mengungkapkan gagasan, ide, pendapat sehingga belum memiliki sifat kritis dalam proses belajar. Secara khusus terdapat kesulitan belajar yang dialami oleh siswa pada materi pembelajaran yang menuntut pemahaman terhadap gambar. Sebagian besar siswa mengalami kesulitan untuk menganalisis gambar, misalnya antara organ dengan fungsi organ pada makhluk hidup, sehingga mempengaruhi tingkat penguasaan konsep.Untuk menciptakan suasana belajar yang aktif,kreatif,dan efektif perlu menerapkan pembelajaran di kelas.

Berdasarkan permasalahan yang telah terindentifikasi diperlukan upaya untuk mengatasi permasalahan belajar siswa, dengan menerapkan pembelajaran aktif sekaligus menyenangkan.Potensi belajar pada siswa yang masih senang bermain akan dimanfaatkan untuk mengatasi permasalahan jumlah siswa yang belum tuntas belajar IPA. Sesuai dengan kesulitan belajar siswa yang telah teridentifikasi, maka akan ditempuh model pembelajaran yang dapat membantu siswa menguasai konsep, sekaligus membuat siswa belajar yang menyenangkan. Dalam penelitian ini model yang akan digunakan examples non examples dengan berbantuan powerpoint. Pembelajaran model examples non examples dapat meningkatkan pemahaman konsep IPA sehingga hasil belajar siswa meningkat.

Model examples non examples adalah suatu model pembelajaran yang menggunakan gambar yang sesuai dengan kompetensi dasar. Example Non example adalah teknik yang dapat digunakan untuk mempercepat penguasaan konsep siswa. Model ini bertujuan untuk mempersiapkan siswa secara cepat dengan menggunakan 2 hal yang terdiri dari example dan non-example dari suatu definisi konsep yang ada, dan meminta siswa untuk mengklasifikasikan keduanya sesuai dengan konsep yang ada. Example memberikan gambaran akan sesuatu yang menjadi contoh akan suatu materi yang sedang dibahas, sedangkan non-example memberikan gambaran akan sesuatu yang bukanlah contoh dari suatu materi yang sedang dibahas. Model examples non examples dipilih untuk mengatasi belajar siswa karena memiliki keunggulan, yaitu : (1) siswa lebih kritis dalam menganalisa gambar (2) siswa mengetahui aplikasi dari materi berupa contoh gambar (3) siswa diberi kesempatan untuk mengemukaakan pendapat.

Langkah-langkah Model Examples Non Examples sebagai berikut :(1) Guru mempersiapkan gambar-gambar sesuai dengan tujuan pembelajaran (2).Guru menempelkan gambar di papan atau ditayangkan melalui OHP, memberikan gambar pada peserta didik (3).Guru memberi petunjuk dan memberi kesempatan pada peserta didik untuk memperhatikan/menganalisa gambar (4).Melalui diskusi kelompok, hasil diskusi dari analisa gambar tersebut dicatat pada kertas (5).Dari 


\section{SHEs: Conference Series $x(x)(20 x x) 00-00$}

beberapa kelompok diberi kesempatan membacakan hasil diskusinya (6).Mulai dari komentar/hasil diskusi peserta didik, guru mulai menjelaskan materi sesuai tujuan yang ingin dicapai (7).Kesimpulan.

Model examples non examples sebagai strategi belajar mengajar yang mengupayakan siswa untuk lebih memahami materi pelajaran, sehingga dalam belajar IPA tidak sekedar menghafal materi pelajaran saja. Dengan model examples non examples dapat membuat siswa dengan mudah memahaminya. Siswa yang belajar dengan menggunakan gambar akan meningkatkan kualitas ke-terlibatan siswa dalam proses belajar mengajar, sehingga siswa akan berperan secara aktif dan meningkatkan motivasi belajar siswa. Guru meminta siswa untuk mengamati atau menganalisis gambar sehingga siswa akan berusaha memahami gambar tersebut. Gambar merupakan media visual yang penting. Dikatakan penting sebab dapat menggantikan kata verbal, mengkongkritkan yang abstrak, dan mengatasi pengamatan manusia. Gambar membuat orang dapat menangkap ide atau informasi yang terkandung di dalamnya dengan jelas, lebih jelas daripada yang diungkapkan oleh kata-kata.

Model Examples Non Examples merupakan model pembelajaran yang menggunakan gambar sebagai media pembelajaran. Penggunaan media gambar ini disusun dan dirancang agar anak dapat menganalisis gambar tersebut menjadi sebuah bentuk diskripsi singkat mengenai apa yang ada didalam gambar. Penggunaan Model Pembelajaran Examples Non Examples ini lebih menekankan pada konteks analisis siswa.

Gambar sebagai obyek pembelajaran dalam IPA perlu divisualisasikan dengan tampilan yang menarik agar memicu perhatian siswa. Sadiman dalam Rahyu (2011) "media" berasal dari kata "medium" yang berarti perantara atau pengantar dalam menyampaikan pesan komunikasi. Media pembelajaran adalah segala sesuatu yang dapat digunakan untuk menyalurkan pesan (ba-han pembelajaran), sehingga dapat merangsang perhatian, minat, pikiran, dan perasaan siswa dalam kegiatan belajar untuk mencapai tujuan belajar. Oleh karena proses pembelajaran merupakan proses komunikasi dan berlangsung dalam suatu sistem, maka media pembelajaran menempati posisi yang cukup penting sebagai salah satu komponen sistem pembelajaran. Media salah satu sumber belajar yang dapat merangsang siswa belajar. Dalam proses belajar mengajar harus terjadi komunikasi antara guru sebagai sumber pesan dengan siswa sebagai penerima pesan.

Menurut Wijaya dalam Astuty (2012) media berperan sebagai perangsang belajar dan dapat menumbuhkan motivasi belajar sehingga siswa tidak menjadi bosan dalam meraih tujuan-tujuan belajar. Dalam pembelajaran media memiliki fungsi antara lain : mengatasi hambatanproses komunikasi, sikap pasif siswa dalam bela-jar dan mengatasi keterbatasan fisik siswa (Mur-tini , 2011).

Mikrosof Power point salah satu media jenis proyektor. Keunggulan powerpoint adalah: (1) mudah menggunakannya, (2) mudah dan dapat diproduksi oleh guru sendiri, (3) dapat digunakan secara individu, (4) dapat diulang-ulang sehingga lebih efisien, (5) biaya tidak mahal, (6)memiliki daya tarik, (7) fleksibel penggunaannya,(8) dapat digunakan beberapa kali untuk kelasyang sama maupun berbeda. Hasil penelitian Angeline dan Utomo (2012) media powerpoint dapat meningkatkan hasil belajar siswa

Ketepatan penggunaan media power point yaitu dapat membantu pencapaian keberhasilan belajar siswa. Penggunaan media power point adalah salah satu alat bantu yang digunakan pada saat proses pembelajaran berlangsung. Dengan penggunaan media power point akan memudahkan siswa dalam memahami materi yang disampaikan. Penggunaan media power point tentunya juga akan melatih

daya ingat siswa karena terdapat penggunaan warna dalam slide power point.Pembelajaran yang menarik seperti ini akan menjadikan pembelajaran yang 
sangat menyenangkan.

Materi pembelajaran yang divisualisasikan dengan tepat akan berdampak pada penguasaan konsep siswa sehingga hasil belajarnya meningkat. Hasil yang dicapai dari suatu usaha yang dilakukan atau dikerjakan disebut hasil belajar(Sadimin, 2011). Hasil belajar merupakan nilai yang diperoleh siswa pada akhir satuan pelajaran yang diukur dengan tes. Siswa dikatakan berhasil dalam belajar apabila telah mencapai prestasi belajar yang diharapkan. Faktor-faktor yang mempengaruhi hasil belajar yaitu faktor internal dan ekternal. Faktor internal yaitu faktor yang berasal dari dalam diri siswa baik yang bersifat fisiologis seperti kondisi jasmaniah maupun bersifat psikologis. Sedangkan faktor eksternal yaitu faktor yang berasal dari luar diri siswa seperti lingkungan. Menurut Winkle dalam Mahrani (2013)bahwa " hasil belajar adalah bukti keberhasilan yang dicapai oleh siswa. Jadi dapat disimpulkan bahwa hasil belajar adalah bukti yakni nilai /Prestasi yang didapat siswa".

Dengan Pembelajaran model examples non examples berbantuan powerpoint selain siswa ter-motivasi dalam belajar, juga akan meningkatkan pemahaman konsep sehingga dapat meningkatkan hasil belajar. Melalui model exaimples non examples dapat memperjelas pemahaman siswa tentang materi pembelajaran. Siswa dilatih untuk manganalisis dan mendiskusikan materi pelajaran melalui contohcontoh yang disajikan.Penerapan model examples non examples membuat siswa lebih termotivasi dan lebih aktif dalam mengikuti pembelajaran.

Hasil penelitian Dwita (2009) menunjukkan bahwa model pembelajaran Examples Non Examples dapat meningkatkan motivasi dan hasil belajar biologi siswa kelas VII-B SMP Negeri 2 Sukorejo Pasuruan. Selain itu menurut Lagandja (2008) bahwa pembelajaran kooperatif model examples non examples dapat meningkatkan hasil belajar Biologi dengan ketuntasan belajar $88 \%$ dan nilai rata-rata 86 Tujuan penelitian ini adalah untuk megetahui apakah pembelajaran model examples non examples berbantuan power-point dapat meningkatkan hasil belajar IPA pada siswa kelas V SDN Karanggintung 05.

\section{METODE}

Penelitian ini dilaksanakan di SDN Karanggintung 05 Desa Karanggintung Kecamatan Gandrungmangu. Subyek penelitian adalah peserta didik kelas $\vee$ yang terdiri 12 siswa, 6 perempuan dan 6 laki-laki. Teknik pengumpulan data yang digunakan ada 2 cara yaitu teknik tes dan non tes. Teknik tes berupa : ulangan harian, teknik non tes berupa : lembar observasi .

Tindakan yang dilakukan dalam rancangan penelitian sebagai berikut: (1) Menyusun Rencana Pelaksanaan Pembelajaran dengan menggunakan model examples non examples. (2) Mempersiapkan sumber, bahan dan alat bantu yang dibutuhkan. (3) Menyusun instrumen penilaian yaitu kisi-kisi dan naskah soal evaluasi (4 ) Mempersiapkan lembar kerja siswa ( LKS ) dan (5) Menyusun lembar aktivitasi siswa .

Prosedur penelitian ini direncanakan tindakan sebanyak 2 siklus. Setiap siklusnya disusun dengan langkah-langkah sebagai berikut : perencanaan, pelaksanaan tindakan, pengamatan dan refleksi.

\section{HASIL DAN PEMBAHASAN}

Hasil analisis nilai siswa mengerjakan soal tes/ evaluasi pada akhir siklus I diperoleh nilai rata-rata kelas sebesar 73. Banyaknya siswa yang memperoleh lebih dari atau sama dengan 75 sebanyak 8 siswa dari 12 siswa,sehingga pencapaian ketuntasan belajar siswa adalah sebesar $67 \%$. Hal ini menunjukkan bahwa ketuntasan klasikal belum mencapai minimal ketuntasan klasikal $80 \%$ dari jumlah siswa. 
Berdasarkan observasi dalam siklus 1 pengelolaan kelas masih kurang karena harus mengkondisikan peserta didik untuk belajar secara berkelompok. Selain itu, waktu yang digunakan kurang tepat karena guru harus menjelaskan pembelajaran model examples non examples terlebih dahulu. Siswa belum terbiasa mengerjakan tugas secara berkelompok jadi masih menonjolkan individu, siswa belum menghargai gagasan sesama teman, dan kurang berani mempresentasikan hasil diskusinya.Hasil analisis siklus 2 nilai siswa mengerjakan soal tes/ evaluasi pada akhir siklus II diperoleh jumlah nilai 2860 dan nilai rata-rata kelas sebesar 79 . Banyaknya siswa yang memperoleh lebih dari atau sama dengan 75 sebanyak 10 siswa dari 12 siswa, sehingga pencapaian ketuntasan belajar siswa adalah belajar siswa adalah sebesar $80 \%$. Hal ini menunjukkan bahwa ketuntasan klasikal sudah mencapai minimal ketuntasan klasikal $80 \%$ dari jumlah siswa. Observasi pada siklus 2 waktu yang digunakan sudah tepat karena materi nya cukup mudah dan ringan. Siswa mulai terbiasa mengerjakan tugas secara berkelompok, tapi siswa sudah menghargai gagasan sesama teman, tidak menonjolkan sifat individunya.

Tabel 1. Rekapitulasi Nilai

\begin{tabular}{lcc}
\hline Keterangan & Siklus 1 & Siklus 2 \\
\hline Rata-rata nilai & 73 & 79 \\
Jumlah siswa tuntas belajar & 8 & 10 \\
Jumlah siswa yang belum tuntas & 4 & 2 \\
Presentase ketuntasan belajar & $67 \%$ & $80 \%$ \\
\hline
\end{tabular}

Adapun hasil dari setiap siklus jika dilihat dalam bentuk grafik seperti pada Gambar 1.

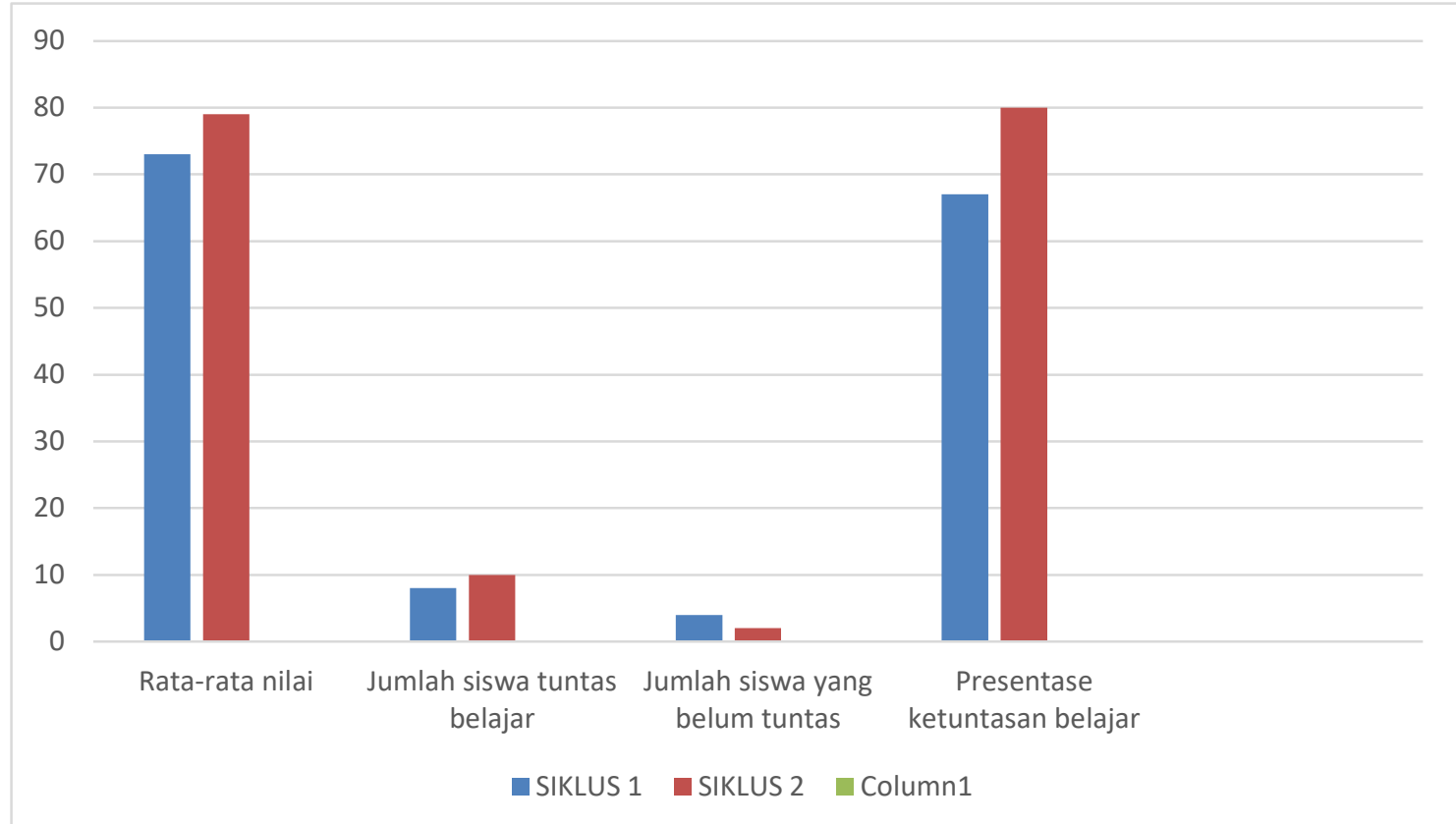

Gambar 1. Rekap rata-rata nilai, jumlah siswa tuntas belajar, jumlah siswa yang belum tuntas dan prosentase ketuntasan belajar.

Dari Gambar 1 dapat diketahui bahwa kenaikan rata-rata nilai dari siklus 1 ke siklus 2 adalah 7 . Sesuai dengan indikator yaitu ada peningkatan rata-rata nilai ulangan harian.

Kenaikan prosentase ketuntasan belajar siswa dari siklus 1 ke Siklus 2 adalah 6 $\%$. Sesuai dengan indikator keberhasilan yang telah ditetapkan, maka peningkatan ketuntasan belajar siswa memenuhi kriteria ketuntasan minimal $80 \%$ dari jumlah 


\section{SHEs: Conference Series $x(x)(20 x x) 00-00$}

siswa, sehingga penelitian tindakan ini dikatakan berhasil meningkatkan hasil belajar siswa yang berupa peningkatan ketuntasan belajar dan rata-rata nilai ulangan harian.

\section{SIMPULAN}

Hasil pelaksanaan pembelajaran IPA dengan menggunakan model examples non examples berbantuan powerpoint, penulis menarik kesimpulan sebagai berikut : Pembelajaran kooperatif model examples non examples berbantuan powerpoint dapat meningkatkan hasil belajar IPA di kelas V SDN Karanggintung 05.Memperhatikan proses dan hasil belajar dengan menggunakan model examples non examples berbantuan powerpoint di kelas SDN Karanggintung 05 , penulis menyampaikan saransaran sebagai berikut : untuk meningkatkan hasil belajar dan kerjasama dalam belajar pada siswa, guru perlu mencoba pembelajaran model examples non examples berbantuan powerpoint pada materi atau pokok bahasan yang lain.

\section{DAFTAR PUSTAKA}

Aini, Putri Nur. 2015. Penerapan Metode Example Non Example dan Media Visual Untuk Meningkatkan Hasil Belajar Pada Mata Pelajaran IImu Pengetahuan Alam (IPA) Siswa Kelas III MI Tarbiyatul Banin Walbanat Kedungsigit Karangan Trenggalek.

Angeline, N dan Utomo, P. 2012. Peningkatan Hasil Belajar Siswa Menggunakan Media Power point dan Animasi Berbasis Macromedia Flash dengan Model Explicit Instruction Pada Mata Pelajaran Desain Grafis Kelas XI IPA di SMA Negeri 11 Yogyakarta. Jurnal UNY, 1 (4). http://Journal.Student.uny.ac.id/artikel. diunduh 15 Februari 2014.

Astuty, N. 2012. Penerapan Model Pembelajaran Kooperatif Tipe Examples non Examples Dengan Menggunakan Alat Peraga Untuk Meningkatkan Hasil Belajar Siswa di Kelas VIII. Jurnal Exacta, 10 (1).

Dwita, M.S. 2009. Pengaruh model pembelajaran Examples Non Examples terhadap motivasi dan hasil belajar biologi siswa kelas VII-B SMP Negeri 2 Sukorejo Pasuruan. (Skripsi). Malang: Jurusan Biologi Fakultas MIPA UM. http://Karyall-miah-um.ac.id. diakses tanggal 18/11/2013.

Jurnal Untan, 3586-3600. jurnal.untan.ac.id/index.php/jpdpb/article/download/3586/3600. diunduh tanggal 8 Februari 2014.

Lagandja. 2008. Meningkatkan Hasil Belajar Biologi Dengan menggunakan Model Pembelajaran Examples Non Examples Di SMA N 3 Goron-talo. Jurnal Penelitian dan Pendidikan, 5: 219-229.

Mahrani. 2013. Peningkatan Hasil Belajar Matematika Menggunakan Pembelajaran Powerpoint..

Murtini, S. 2011. Ketrampilan Menyimak Cerpen Melalui Media Kaset Audio Pada Siswa Kelas IX D SMP Negeri 1 Tegal Tahun 2010/2011. Pedagogik Jurnal Pendidikan Dasar dan Menengah. 5 (1): 97-104.

Rahyu. 2011. Media Pembelajaran. http://skripsi-tesiskaryailmiah.blogspot.com2011/04/mediapembelajaran.html

Sadimin. 2011. Penggunaan Teknologi Tepat Guna Dalam Pembelajaran Gerak Melingkar Dengan metode Eksperimen Sebagai Upaya Untuk Meningkatkan Hasil Belajar Siswa pada kelas XI.IPA 1 SMA Negeri 3 Brebes Tahun Pela-jaran 2009/2010. Pedagogik Jurnal Pendidikan Dasar dan Menengah. 5 (1): 85-96. 